\section{New Guinea Impatiens Growth Response and Nutrient Release from Controlled- release Fertilizer in a Recirculating Subirrigation and Top-watering System}

\author{
Daphne L. Richards ${ }^{1}$ and David Wm. Reed ${ }^{2}$ \\ Department of Horticultural Sciences, Texas A\&MUniversity, College Station, \\ TX 77843-2133 \\ Additional index words. ebb-and-flow, ebb-and-flood, slow-release fertilizer, Osmocote, \\ $\mathrm{CRF}$, plant nutrition, nitrogen, potassium, phosphorus
}

\begin{abstract}
New Guinea impatiens (Impatiens hawkeri Bull.) 'Illusion' were grown in a recirculating subirrigation system under various rates and placements of $14 \mathrm{~N}-6.1 \mathrm{P}-11.6 \mathrm{~K}$ (Osmocote; Scotts-Sierra, Marysville, Ohio) resin-coated, controlled-release fertilizer (CRF). Four CRF placements (incorporated, top-dressed, bottom, and dibble) were tested. Incorporated placement yielded slightly greater dry weights than the other placements. A rate experiment tested incorporating from 0.5 to 2 times the fertilizer manufacturer's recommended rate of $7.11 \mathrm{~kg} \cdot \mathrm{m}^{-3}$. All shoot growth parameters (height, leaf number, shoot, and root fresh and dry weight) exhibited a significant quadratic response, as exemplified by shoot dry weight, where shoot dry weight increased up to the $1.5 \times$ rate, after which shoot dry weight decreased. A quadratic response surface model revealed that the optimum rate response ranged from $1.16 \times$ rate for height to $1.47 \times$ rate for shoot dry weight. The lower bound of the $95 \%$ confidence interval (CI) would be the lowest rate at which one could expect maximum growth response. The lower bound of the $95 \% \mathrm{CI}$ varied from $0.56 \times$ rate for height to $1.30 \times$ rate for shoot dry weight. Thus, the lowest rate that would be within the $95 \%$ CI for all growth parameters, and thus yield maximum growth response, would be the $1.30 \times$ rate. Electrical conductivity (EC) of the growing media increased significantly with increasing CRF rate. At all rates, $\mathrm{EC}$ was significantly greater in the top layer than in the middle and bottom layers. Only in the $1.75 \times$ and $2 \times$ rates did EC exceed the recommended EC levels in the middle and bottom layer. All rates $>0.75 \times$ exceeded recommended EC in the top layer. Release characteristics and total nutrient balance of the CRF was compared in subirrigated and top-watered systems. There was no significant difference between top-watered and subirrigated treatments for the amount of $K$ recovered in plant tops and released from prills. By day 84 , in subirrigation, $46 \%$ of the $K$ was still in the prills, $41 \%$ was recovered in the plant tops, and $22 \%$ was recovered in the medium. Similar results were obtained in the top-watering treatment, except that a lesser amount was recovered in the medium $(9 \%)$ and a small amount $(4 \%)$ was recovered in the leachate. The uptake of $K$ by plants and release of $K$ by the CRF were inversely proportional and linear with respect to time. Of the $\mathrm{K}$ released from the prills, $77 \%$ and $\mathbf{8 3 \%}$ were recovered in the plant tops for subirrigation and top-watering, respectively, indicating very high fertilizer use efficiency.
\end{abstract}

The high value of greenhouse and nursery crops dictates intensive production methods. Frequent irrigation and fertilization, as well as the use of chemical growth retardants and pesticides, are common practices in the greenhouse/nursery industry. These production

Received for publication 12 Apr. 2003. Accepted for publication 1 Aug. 2003. We thank Oglevee Ltd., Connellsville, Pa., Scotts-Sierra Co., Marysville, Ohio, and Sun Gro, Terrell, Texas, for providing plant material, fertilizer, and growing medium, respectively, and grant support from the Texas Ornamental Enhancement Program and The Fred C. Gloeckner Foundation, Inc. We thank Dr. George Fernandez, Dept. Applied Economics and Statistics, Univ. of Nevada-Reno, and Matt Kent for assistance on the statistical analysis. Use of trade names does not imply endorsement of products named or criticism of similar products not mentioned. Part of the Master of Science thesis of D.L. Richards. ${ }^{1}$ Graduate Student

${ }^{2}$ Professor; to whom reprint requests should be addressed.E-mail address: dwreed@tamu.edu

practices have led to ground and surface water contamination, and regulations to control environmental pollution by the greenhouse/nursery industry are increasing (Molitor, 1990; Reed, 1996). In the interest of curbing pollution of our natural resources, fertilization practices may need to be modified (Biernbaum, 1992).

The use of controlled-release fertilizers (CRF) may reduce the amount of fertilizer runoff from greenhouse crops, especially when combined with zero-leach irrigation systems (Reed, 1996). The most common zero-leach system is recirculating subirrigation, which completely eliminates leaching and runoff, and is becoming increasingly popular with greenhouse growers, especially in Europe (Molitor, 1990). Both CRF and recirculating subirrigation can increase fertilizer efficiency and decrease fertilizer runoff in greenhouse crops (Biernbaum, 1992), but few studies have been conducted that combine both methods (Morvant et al., 2001).
The objectives were to determine the optimum rate and placement of CRF for growing New Guinea impatiens in a recirculating subirrigation system, and characterize the release rates of CRF and nutrient balance in subirrigation vs. top-watering.

\section{Materials and Methods}

Rate $\times$ placement experiment. New Guinea impatiens 'Illusion' (Impatiens hawkeri Bull.) rooted cuttings (Oglevee Ltd., Connelsville, Pa.) were transplanted into $11-\mathrm{cm}$-wide $\times 9.5-$ cm-tall (460-mL) plastic containers on 9 Oct. 1997. Soilless growing medium used was a peat-perlite based mix, adjusted for $\mathrm{pH}(\approx 5.6)$ and with no preplant nutrient charge (Sunshine no. 2; Sun Gro Horticulture, Terrell, Texas), and amended with $0.5 \mathrm{~kg} \cdot \mathrm{m}^{-3}$ Micromax trace element mix (Grace-Sierra, Milpitas, Calif.). Newly transplanted plants were top-watered once with reverse osmosis-purified water (RO) to settle the medium. After drainage, pots were placed into subirrigation trays. Subirrigation started on 13 Oct. and was terminated on 11 Dec. 1997 (day 63). The experiment was conducted in a glasshouse with an average daily noontime temperature and light intensity of $23.3 \pm 2.1^{\circ} \mathrm{C}$ and $462 \pm 388 \mu \mathrm{mol} \cdot \mathrm{m}^{-2} \cdot \mathrm{s}^{-1}$ photosynthetic photon flux $(P P F)$ (Quantum Light Logger model 3600; Spectrum Technologies, Plainfield, Ill.), respectively.

Experimental design was an incomplete factorial of four CRF rates of $0.25,0.5,0.75$, and 1.0 times the recommended label rate (1.78, $3.56,5.33$, and $7.11 \mathrm{~kg} \cdot \mathrm{m}^{-3}$, respectively) times two CRF placements (incorporated and topdressed), plus 0.5 times the label rate with two additional placements (dibble and bottom); with 10 plants harvested per treatment. Osmocote $14 \mathrm{~N}-6.1 \mathrm{P}-11.6 \mathrm{~K}, 3$ to 4 month release, resin-coated CRF (Scotts-Sierra, Marysville, Ohio) was either incorporated throughout the medium, applied as a top-dress, dibble applied into the bottom of the planting hole, or layered $1 \mathrm{~cm}$ from the bottom of container. Plants were placed in subirrigation trays $(100 \times 110-\mathrm{cm}$ subirrigation trays, Midwest Growmaster, St. Charles, Ill.). Tensiometers (model MLT; Irrometer Co., Riverside, Calif.) were placed in an extra pot with plant (not considered for experimental results) in each tray, and plants were watered when the medium moisture tension exceeded $7 \mathrm{kPa}$. At each irrigation, trays were flooded to a depth of $2 \mathrm{~cm}$ with RO purified water. Trays required 2 to $3 \mathrm{~min}$ to fill, 2 to $3 \mathrm{~min}$ to drain, and were held flooded for 10 min, or until the tensiometer reading returned to $0 \mathrm{kPa}$ and the surface of the medium was rewetted.

Plant height (soil surface to top of tallest leaf), leaf number. and flower number (opened flowers) were measured weekly until final harvest (day 63). At final harvest, plant tops were cut off at the medium surface, and leaf area (model AM82 leaf area meter; Delta-T Devices Ltd., Cambridge, U.K.) and fresh weight were measured. Plant tops were dried at $40{ }^{\circ} \mathrm{C}$ for $48 \mathrm{~h}$, and then weighed for dry weight. The growing medium of each pot was cut into three equal-sized horizontal lay- 
ers (top, middle, and bottom), air-dried, and subsamples were removed from each layer to determine electrical conductivity (EC) and $\mathrm{pH}$ by the 1:2 dilution method (Warncke and Krauskopf, 1983). Prills were not removed since preliminary studies demonstrated no significant effect of prill removal on EC or $\mathrm{pH}$ (data not shown). EC was measured using a conductivity/TDS meter (model 44600; Hach, Co., Loveland, Colo.) and $\mathrm{pH}$ was measured using a model 701 ApH meter(Orion Research, Cambridge, Mass.).

Rate experiment. This experiment was to better define the effect of rate using incorporated placement. Rooted cuttings of Impatiens hawkeri 'Illusion' were transplanted as in the rate $\times$ placement experiment. The experimental design was a single factorial design of CRF rates of $0.5,0.75,1.0,1.25,1.5,1.75$, and 2.0 times the recommended label rate $(3.56,5.33$, $7.11,8.89,10.67,12.44$, and $14.22 \mathrm{~kg} \cdot \mathrm{m}^{-3}$, respectively), with 10 plants harvested per treatment. The experiment started on 8 Apr.and was terminated on 9 June 1998 (day 63). In addition to those parameters measured in the rate $\times$ placement experiment, root fresh and dry weights were determined. Average daily noontime greenhouse temperature and light intensity were $23.2 \pm 2.3{ }^{\circ} \mathrm{C}$ (HOBO sensor; Spectrum Technologies) and $840 \pm 363$ $\mu \mathrm{mol} \cdot \mathrm{m}^{-2} \cdot \mathrm{s}^{-1} P P F$, respectively. All other methods and procedures were as in the rate $x$ placement experiment.

Release rate experiment. This experiment was designed to determine the total nutrient balance and release characteristics of Osmocote $14 \mathrm{~N}-6.1 \mathrm{P}-11.6 \mathrm{~K}$ CRF when used in recirculating subirrigation vs. top-watering. The experiment started on 15 Sept. 1998 and was terminated on 8 Dec. 1998 (day 84). Rooted cuttings of Impatiens hawkeri 'Illusion' were transplanted as in previous experiments. The recommended CRF label rate of $7.11 \mathrm{~kg} \cdot \mathrm{m}^{-3}$ ( $4.47 \mathrm{~g}$ per $460 \mathrm{~mL}$ pot) was used and plants were either subirrigated or top-watered. CRF prills were incorporated into the media, and were counted prior to incorporation and upon removal from media (to ensure all were recovered for analysis).

The experiment was conducted in a growth chamber with temperature set points of $21^{\circ} \mathrm{C}$ days $/ 18{ }^{\circ} \mathrm{C}$ nights, a photoperiod of $16 \mathrm{~h}$ (0600 to $2200 \mathrm{HR}$ ), and a light intensity of 650 $\mu \mathrm{mol} \cdot \mathrm{m}^{-2} \cdot \mathrm{s}^{-1} P P F$.

Fifty subirrigated plants were placed in subirrigation trays, each containing 25 plants, while 50 top-watered plants were placed on an adjacent wire bench. As in previous experiments, tensiometers were used to monitor growing medium moisture tension and determine irrigation timing. When top-watering, a leaching fraction (fraction of water applied that was collected as leachate) of 0.4 was collected in a cup placed beneath each pot. After each watering, leachate volume was measured and 1-mL samples were frozen at $-5{ }^{\circ} \mathrm{C}$ for later analysis. Since the leachate volumes were consistent between waterings, samples from each watering were pooled to avoid excessive analysis.

Five randomly selected plants were har- vested biweekly from each treatment until experiment termination. At each harvest, total nutrient balance of $\mathrm{K}$ was determined for plant tops, media + roots, recirculated irrigation water, leachate, and incorporated fertilizer prills at each harvest. Plant tops were cut off at the surface of the medium, dried and ground to pass through a 20-mesh screen in a Wiley mill, and stored for later digestion via nitric acid plant tissue digest (Havlin and Soltanpour, 1980) for K analysis. Media (with roots) were divided into thirds as in previous experiments. The CRF prills were removed by hand from each layer and stored in $20-\mathrm{mL}$ plastic vials at room temperature $\left(24^{\circ} \mathrm{C}\right)$ for later analysis. For analysis of prills, $15 \mathrm{~mL}$ of $0.1 \mathrm{~N} \mathrm{HCl}$ was added to the vials and prills were allowed to sit overnight. Prills were then sonicated (model 60, Sonic Dismembrator; Fisher Scientific Co., Pittsburgh) until completely broken up. The resulting slurry was brought to $1 \mathrm{~L}$ volume with nanopure water, stirred, filtered, and analyzed for $\mathrm{K}$. The growing medium was air-dried, after removal of the prills, sieved through a \#8 sieve, and then extracted by the Mehlich III acid extraction procedure (Tran and Simard, 1993) for K analysis.

All samples were assayed for $\mathrm{K}$ content by Inductively Coupled Plasma-Atomic Emission Spectrometry (ICP-AES) (Dahlquist and Knoll, 1978). Potassium was chosen as a marker for release rate and distribution because $\mathrm{K}$ does not form complexes (unlike P), $\mathrm{K}$ exists in only one form (unlike $\mathrm{N}$, which can be present as ammoniacal and/or nitrate $\mathrm{N}$ ), and $\mathrm{K}$ is not subject to volatilization (unlike several $\mathrm{N}$ forms).

Amount of $\mathrm{K}$ in each sample was determined for plant tops, media + roots, prills, leachates (for top-watered pots), and recirculated irrigation solution (for subirrigated pots). The initial $\mathrm{K}$ in plants and medium at zero time was subtracted from timed harvest measurements. In addition, five $4.47-\mathrm{g}$ samples of unused prills were analyzed to determine the initial amount of $\mathrm{K}$ added to each pot. Analysis revealed $0.57680 \mathrm{~g} \mathrm{~K}$ per $4.47 \mathrm{~g}$ prills $(12.9 \% \mathrm{~K})$ added per pot, which exceeds the manufacturer's label analysis of $0.51852 \mathrm{~g} \mathrm{~K}$ per $4.47 \mathrm{~g}$ prills (based on $11.6 \%$ $\mathrm{K}$ analysis). For calculating nutrient balance, the analytically measured $0.57680 \mathrm{~g} \mathrm{~K}$ added per pot was used.

Statistical analysis was analysis of variance by SAS. The optimum rates were determined with a quadratic response surface model (SAS RSREG), and the lower and upper 95\% CIs were determined with PROC GLM.

\section{Results and Discussion}

Rate $\times$ placement experiment. In subirrigation, water movement is primarily upward; hence this study was conducted to determine the effectiveness of top-dressed vs. other methods that incorporated the CRF into the medium. There was a significant effect of rate on all growth parameters measured, except leaf chlorophyll(Table 1). As rate increased, growth parameters increased. There was a significant effect of fertilizer placement on all growth parameters, except height (Table 1). When comparing plants grown at the $0.5 \times$ rate with the four different CRF placements, incorporated placement produced slightly greater shoot fresh and dry weight, leaf number and leaf area than the other three placements (Table 1). Using surface applied irrigation, similar placement results were found by Johnson and Warden (1975) using Celosia argentia L. Ann., and by Rauch (1989) using areca palm seedlings. In addition, Oertli and Lunt (1962) found that top-dressed CRF released nutrients much more slowly than incorporated CRF.

When CRF was incorporated throughout the growing medium, EC of all layers increased with increasing fertilizer rate (Table 2). When CRF was top-dressed, EC did not increase with increasing fertilizer rate in the middle and bottom layers. EC of the layers with the dibble placement was similar to top-dress placement. EC of the layers with the bottom placement was highest in the top and bottom layers. Growing medium EC was highest in the top one-third of the pot, regardless of placement. These results are similar to those found in previous studies showing increasing EC with increasing CRF rate and increased EC in the top layer as compared to the middle and bottom layers (Argo and Biernbaum, 1995).

The differences in plant growth between placements at the $0.5 \times$ rate (Table 1 ) were not as large as differences in EC between the placements and layers (Table 2). This may be because EC did not exceed the upper recommended level of either $1.2 \mathrm{dS} \cdot \mathrm{m}^{-1}$ (Lang, 1996) or $1.5 \mathrm{dS} \cdot \mathrm{m}^{-1}$ (Warncke and Krauskopf, 1983) in any layer with any placement, except the top-dressed treatment at the $1 \times$ rate.

Rate experiment. Plants exhibited increasing size with increasing fertilizer rate up to the $1.5 \times$ rate, above which size decreased (Fig. 1). Plants grown at the $0.5 \times$ rate had smaller leaves with more purple coloration and were generally less robust than plants in other treatments. No specific symptoms (necrosis, marginal cupping, etc.) of salt injury were noticed, even at the highest fertilization rates.

All growth parameters measured showed significant differences with increasing fertilizer rate (Table 3). Root growth (fresh and dry weight) decreased dramatically at the higher rates. All shoot growth parameters exhibited a significant quadratic response (Table 3), as exemplified by shoot dry weight, where shoot dry weight increased up to the $1.5 \times$ rate, after which shoot dry weight decreased (Fig. 2). The quadratic response surface model revealed that the optimum rate response ranged from $1.16 \times$ rate for height to $1.47 \times$ rate for shoot dry weight (Table 3). The lower bound of the $95 \%$ CI would be the lowest rate at which one could expect maximum growth response. The lower bound of the $95 \%$ CI varied from $0.56 \times$ rate for height to $1.30 \times$ rate for shoot dry weight. Thus, the lowest rate that would be within the 95\% CI for all growth parameters, and thus yield maximum growth response, would be the $1.30 \times$ rate. These results are similar to other studies in both top-water and subirrigation systems, which have shown that with many species CRF must be used at higher than recom- 
Soll Management, Fertilization, \& Irrigation

Table 1. The effect of rate and placement of CRF on growth response of New Guinea impatiens 'Illusion' grown in a recirculating subirrigation system (final harvest).

\begin{tabular}{|c|c|c|c|c|c|c|c|c|}
\hline \multirow[b]{2}{*}{ Placement $^{\mathrm{y}}$} & \multicolumn{8}{|c|}{ Growth parameter ${ }^{\mathrm{z}}$} \\
\hline & Rate & $\begin{array}{c}\text { Height } \\
(\mathrm{cm})\end{array}$ & $\begin{array}{l}\text { Shoot } \\
\text { fresh st } \\
\quad(\mathrm{g})\end{array}$ & $\begin{array}{l}\text { Shoot } \\
\text { dry wt } \\
\text { (g) }\end{array}$ & $\begin{array}{c}\text { Leaf area } \\
\left(\mathrm{cm}^{2}\right)\end{array}$ & $\begin{array}{l}\text { Chlorophyll } \\
\text { units } \\
\text { (spadmeter) }\end{array}$ & $\begin{array}{c}\text { Leaf } \\
\text { no. }\end{array}$ & $\begin{array}{c}\text { Flower } \\
\text { no. }\end{array}$ \\
\hline \multirow[t]{4}{*}{ Incorporated } & $0.25 x^{x}$ & 12.0 & 38.5 & 2.95 & 284 & 40.1 & 30.3 & 5.3 \\
\hline & $0.5 \times$ & 15.8 & 78.2 & 6.13 & 646 & 46.2 & 65.8 & 9.0 \\
\hline & $0.75 x$ & 17.1 & 86.9 & 6.35 & 931 & 46.3 & 73.7 & 12.8 \\
\hline & $1 \times$ & 19.2 & 111.6 & 7.92 & 1149 & 50.1 & 92.1 & 14.3 \\
\hline \multirow[t]{4}{*}{ Top-dressed } & $0.25 x$ & 10.7 & 31.3 & 2.61 & 291 & 43.9 & 30.2 & 3.6 \\
\hline & $0.5 x$ & 16.6 & 66.3 & 4.99 & 586 & 46.3 & 59.3 & 7.2 \\
\hline & $0.75 x$ & 16.9 & 77.2 & 5.85 & 693 & 50.4 & 68.1 & 7.2 \\
\hline & $1 \times$ & 17.2 & 91.2 & 6.86 & 1018 & 50.8 & 81.3 & 6.9 \\
\hline Bottom & $0.5 x$ & 15.9 & 65.4 & 4.88 & 565 & 46.4 & 59.6 & 4.6 \\
\hline Dibble & $0.5 \times$ & 15.9 & 72.1 & 5.16 & 455 & 46.2 & 56.0 & 16.9 \\
\hline \multicolumn{9}{|c|}{ Significance } \\
\hline Placement & & NS & $* * *$ & $* * *$ & $* * *$ & $* * *$ & $* *$ & $* * *$ \\
\hline Rate & & $* * *$ & $* * *$ & $* * *$ & $* * *$ & NS & $* * *$ & $* * *$ \\
\hline Placement $\times$ rate & & $*$ & NS & NS & $* *$ & $* *$ & NS & $*$ \\
\hline
\end{tabular}

${ }^{\mathrm{z}}$ Data represents means of ten replications.

${ }^{\mathrm{y}}$ Incorporated = incorporated into the medium; Top-dressed $=$ top-dressed on the surface of the medium; Bottom = placed in the bottom $1 \mathrm{~cm}$ of medium; Dibble = applied into the transplant hole.

${ }^{\mathrm{x}} \mathrm{X}=$ manufacturer's recommended rate of $7.1 \mathrm{~kg} \cdot \mathrm{m}^{-3}$.

ns, ${ }^{*}, * *, * * *$ Nonsignificant or significant at $P<0.05,0.01$, or 0.001 , respectively.

Table 2. EC of the top, middle, and bottom layers of growing medium from New Guinea impatiens 'Illusion' grown at varying rates and placements of CRF in a recirculating subirrigation system (final harvest).

\begin{tabular}{|c|c|c|c|c|}
\hline \multirow[b]{2}{*}{ Placement ${ }^{\mathrm{y}}$} & \multirow[b]{2}{*}{ Rate } & \multicolumn{3}{|c|}{$\mathrm{EC}\left(\mathrm{dS} \cdot \mathrm{m}^{-1}\right)^{\mathrm{z}}$} \\
\hline & & Top & Middle & Bottom \\
\hline \multirow[t]{4}{*}{ Incorporated } & $0.25 x^{x}$ & 0.43 & 0.22 & 0.18 \\
\hline & $0.5 x$ & 0.73 & 0.43 & 0.22 \\
\hline & $0.75 x$ & 0.68 & 0.53 & 0.35 \\
\hline & $1 \times$ & 1.24 & 0.70 & 0.55 \\
\hline \multirow[t]{4}{*}{ Top-dressed } & $0.25 x$ & 0.30 & 0.06 & 0.06 \\
\hline & $0.5 x$ & 0.25 & 0.06 & 0.06 \\
\hline & $0.75 x$ & 0.36 & 0.07 & 0.06 \\
\hline & $1 \times$ & 0.41 & 0.07 & 0.06 \\
\hline Bottom & $0.5 x$ & 0.26 & 0.08 & 0.23 \\
\hline Dibble & $0.5 x$ & 0.30 & 0.11 & 0.06 \\
\hline \multicolumn{5}{|c|}{ Significance } \\
\hline Placement & & & $* * *$ & \\
\hline Rate & & & $* * *$ & \\
\hline Layer & & & $* * *$ & \\
\hline Placement $\times$ rate & & & $* * *$ & \\
\hline Placement $\times$ layer & & & $* * *$ & \\
\hline Rate $\times$ layer & & & $* *$ & \\
\hline Placement $\times$ rate $\times$ layer & & & NS & \\
\hline
\end{tabular}

${ }^{2}$ Data represents means of 10 replications.

IIncorporated $=$ incorporated into the medium; Top-dressed $=$ top-dressed on the surface of the medium; Bottom $=$ placed in the bottom $1 \mathrm{~cm}$ of medium; Dibble $=$ applied into the transplant hole.

${ }^{\mathrm{x}} \mathrm{X}=$ manufacturer's recommended rate of $7.1 \mathrm{~kg} \cdot \mathrm{m}^{-3}$.

ns, ${ }^{* *}, * * *$ Nonsignificant or significant at $P<0.01$ or 0.001 , respectively.

mended label rates to achieve optimum growth (Kovacic and Holcomb, 1981; Lamont et al., 1990; Rauch, 1989), including New Guinea impatiens (Rauch and Murakami, 1994). However, Haver and Schuch (1996) found, in a no-leach system at high moisture content, that the biomass of New Guinea impatiens 'Illusion' was greatest at the recommended CRF label rate and biomass decreased at the $1.5 \times$ rate. This may have been caused by high EC levels reported in all layers of the container in the no leach system used.

EC of the growing medium increased with increasing fertilizer rate (Fig. 3). At all rates, EC was significantly higher in the top layer than in the middle and bottom layers. For a 1:2 dilution extraction, $1.2 \mathrm{dS} \cdot \mathrm{m}^{-1}$ (Lang, 1996) to $1.5 \mathrm{dS} \cdot \mathrm{m}^{-1}$ (Warncke and Krauskopf, 1983) are commonly recommended upper limits for EC. At $1 \times$ and higher rates, the EC of the top layer exceeded these recommended EC levels. High $\mathrm{EC}$ in the top layer is not always damaging, probably due to fewer roots in the top layer (Kent and Reed, 1996). Only at the 1.75 and $2 \times$ rate did the EC of the middle layer exceed these recommended EC levels, while the EC of the bottom layer never exceeded the recommended EC at any rate. Growth reduction (Fig. 2) only occurred when the recommended EC was exceeded in both the top and middle layers (Fig. 3).

Growing medium $\mathrm{pH}$ decreased in all layers as rate increased, with the greatest decrease in the top layer (Fig. 3). The $\mathrm{pH}$ decrease can be attributed to nitrification due to the higher level of ammoniacal $\mathrm{N}$ than nitrate $\mathrm{N}$ in Osmocote. When CRF rates are increased, more ammonium is available for nitrification, thus causing the $\mathrm{pH}$ to decrease. These results are similar to those found by Jarrell et al. (1983) and Lamont et al. (1987). These trends in $\mathrm{pH}$ were inversely proportional to the trends of $\mathrm{EC}$, and were probably caused by accumulation of ammoniacal $\mathrm{N}$ as a component of the measured EC.

Release rate experiment. The total $\mathrm{K}$ recovered by the plant/medium/leachate system averaged $105.4 \% \pm 9.8 \%$ (Table 4 ). This level of 


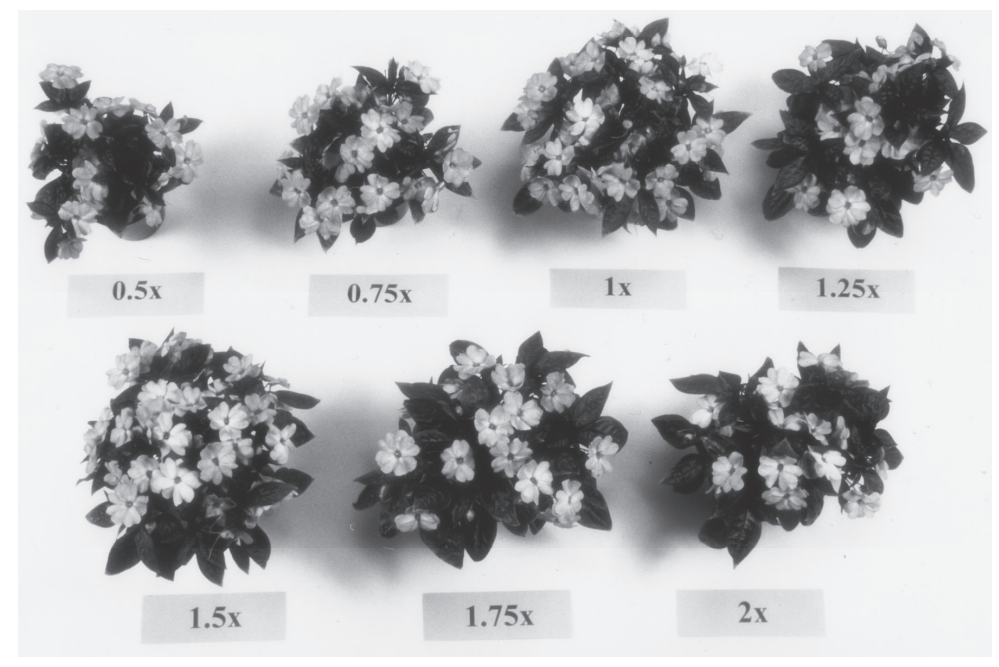

Fig. 1. New Guinea impatiens 'Illusion' grown at rates of $0.5,0.75,1,1.25,1.5,1.75$, and 2 times the recommended rate of CRF in a recirculating subirrigation system (day 63, final harvest).

Table 3. The effect of rate of CRF on growth response of New Guinea impatiens 'Illusion' grown in a recirculating subirrigation system (final harvest).

\begin{tabular}{|c|c|c|c|c|c|c|c|}
\hline \multirow[b]{2}{*}{ Rate } & \multirow[b]{2}{*}{$\begin{array}{l}\text { Height } \\
(\mathrm{cm})\end{array}$} & \multirow[b]{2}{*}{$\begin{array}{c}\text { Leaf } \\
\text { no. }\end{array}$} & \multirow[b]{2}{*}{$\begin{array}{c}\text { Flower } \\
\text { no. }\end{array}$} & \multicolumn{2}{|c|}{ Shoot } & \multicolumn{2}{|c|}{ Root } \\
\hline & & & & $\begin{array}{c}\text { Fresh wt } \\
(\mathrm{g})\end{array}$ & $\begin{array}{l}\text { Dry wt } \\
(\mathrm{g})\end{array}$ & $\begin{array}{c}\text { Fresh wt } \\
(\mathrm{g})\end{array}$ & $\begin{array}{c}\text { Dry wt } \\
(\mathrm{g})\end{array}$ \\
\hline $0.5 x^{y}$ & 15.7 & 50.4 & 25.2 & 60.78 & 4.73 & 13.80 & 0.99 \\
\hline $0.75 x$ & 16.7 & 70.8 & 41.8 & 84.62 & 6.39 & $---x$ & --- \\
\hline $1 \times$ & 16.8 & 86.6 & 48.3 & 108.70 & 8.23 & 13.67 & 1.04 \\
\hline $1.25 x$ & 16.3 & 87.4 & 50.2 & 110.10 & 8.12 & --- & --- \\
\hline $1.5 x$ & 17.1 & 98.8 & 53.6 & 128.08 & 9.42 & --- & --- \\
\hline $1.75 x$ & 16.5 & 88.8 & 49.0 & 123.82 & 8.99 & --- & --- \\
\hline $2 \times$ & 14.5 & 72.3 & 36.2 & 94.43 & 7.39 & 6.72 & 0.54 \\
\hline \multicolumn{8}{|c|}{ Significance } \\
\hline Rate & $* * *$ & $* * *$ & $* * *$ & $* * *$ & $* * *$ & $* * *$ & $* * *$ \\
\hline Quadratic & $* * * *$ & $* * * *$ & $* * * *$ & $* * * *$ & $* * * *$ & --- & --- \\
\hline$R^{2}$ & 0.75 & 0.96 & 0.97 & 0.93 & 0.94 & --- & --- \\
\hline Optimum rate ${ }^{w}$ & 1.16 & 1.40 & 1.35 & 1.45 & 1.47 & --- & --- \\
\hline Lower $95 \% \mathrm{CI}^{\mathrm{v}}$ & 0.56 & 1.25 & 1.22 & 1.28 & 1.30 & --- & --- \\
\hline Upper $95 \% \mathrm{CI}^{\mathrm{w}}$ & 1.76 & 1.54 & 1.47 & 1.62 & 1.63 & --- & --- \\
\hline
\end{tabular}

${ }^{2}$ Data represent means of 10 replications.

${ }^{\mathrm{y}} \mathrm{X}=$ manufacturer's recommended rate of $7.1 \mathrm{~kg} \cdot \mathrm{m}^{-3}$.

${ }^{x}$ Dash indicates data not collected, or insufficient data to calculate.

"Determined by quadratic response surface model SAS RSREG

${ }^{\mathrm{V}} \mathrm{CI}=$ confidence interval; determined by PROC GLM.

******** Significant at $P<0.001$ or 0.0001 , respectively.

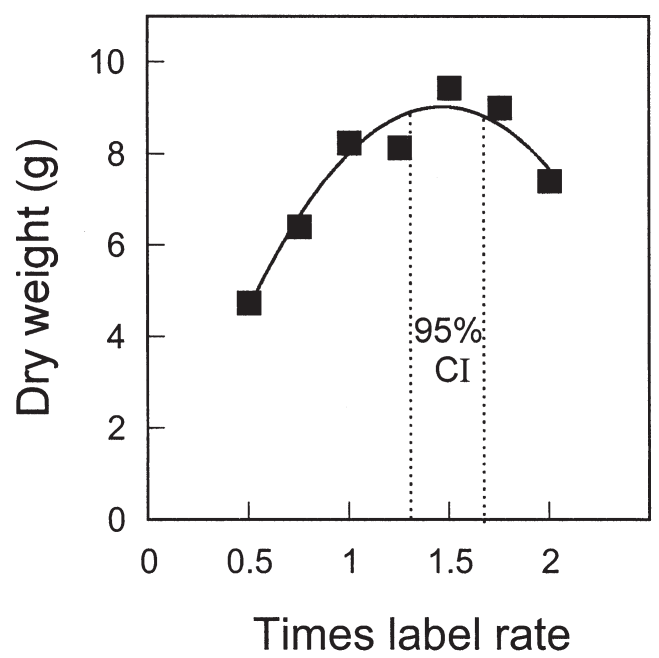

Fig. 2. Shoot dry weight of New Guinea impatiens 'Illusion' grown at rates of $0.5,0.75,1,1.25,1.5,1.75$, and 2 times the manufacturer's recommended rate of CRF in a recirculating subirrigation system (final harvest). Dry weight can be expressed by $y=-4.730 x^{2}+13.877 x-1.164, R^{2}=0.94$, with an optimum rate response of $1.47 \times$ rate, and a $95 \% \mathrm{CI}$ of $1.30 \times$ to $1.63 \times$ rate. variability is acceptable given the complexities of the experimental recovery of $\mathrm{K}$.

There were no significant differences between top-watered and subirrigated treatments for the amount of $\mathrm{K}$ recovered from plant tops and prills. For both subirrigation and top watering, $\mathrm{K}$ content in plant tops significantly (Table 4) and linearly (Fig. 4) increased with time. At final harvest (day 84 ), $\approx 45 \%$ of the $\mathrm{K}$ from the CRF was recovered in the plant tops. Potassium content remaining in the CRF prills significantly decreased with time, and was inversely proportional to $\mathrm{K}$ recovered in the plant tops. At final harvest, $\approx 55 \%$ of the $\mathrm{K}$ had been released from the prill. Similarly, Holcomb (1981), studying K release rates from several CRFs, found there were no significant differences between subirrigation vs. top-watering in recovery of $\mathrm{K}$ in the plant tops or $\mathrm{K}$ release from the prill.

The amount of $\mathrm{K}$ recovered from the growing medium was significantly affected by irrigation method. In subirrigation, the greatest $\% \mathrm{~K}$ tended to be recovered in either the top or middle layer of the growing medium, and in top-watering the $\% \mathrm{~K}$ recovered is more evenly distributed between the layers (Table 4). Fertilizer and irrigation water salts have been shown by previous research to accumulate in the top layer of growing media of subirrigated plants (Argo and Biernbaum, 1995; Haver and Schuch, 1996; Kent and Reed, 1996; Molitor, 1990). At final harvest, the growing medium had accumulated more $\mathrm{K}$ in subirrigation (sum of all layers equals $23 \%$ of the applied $\mathrm{K}$ ) than in top-watering (sum equals $9 \%$ ). This is partially caused by leaching of $\mathrm{K}$ in the topwatering treatment and partially caused by the greater accumulation of $\mathrm{K}$ in the top layer of the subirrigation treatment.

In top-watered treatments, relatively small amounts of the total $\mathrm{K}$ were recovered in the leachates (0.4 leaching fraction). On day 14, $\approx 8 \%$ of the $\mathrm{K}$ was recovered from leachates, however, by day 84 , only $4 \%$ of the $\mathrm{K}$ was recovered from leachates. This indicates that when the plants are newly transplanted and their root systems are not fully developed, they are less efficient at taking up available nutrients compared to later in their life cycles. Thus, early in the crop, the released $\mathrm{K}$ accumulates in the medium and is available for increased leaching. This has been reported for many plants, including New Guinea impatiens (Hartley, 1995). In fact, it is commonly recommended that New Guinea impatiens rooted cuttings or seedlings not be fertilized at all during the first two to three weeks after transplanting (Erwin et al., 1992; Hartley, 1995).

Irrigation solution that had been recirculated in the subirrigated treatments over the course of the experiment was also tested for $\mathrm{K}$ content, but no $\mathrm{K}$ was detected. This would indicate that, as has been reported previously (Reed, 1996), irrigation solution taken up by the growing medium remains there, with no appreciable loss back to the subirrigation tanks. If the container is not flooded too deeply ( 2 $\mathrm{cm}$ in these experiments), the water that enters the container probably remains as a perched water table upon draining. In other words, 


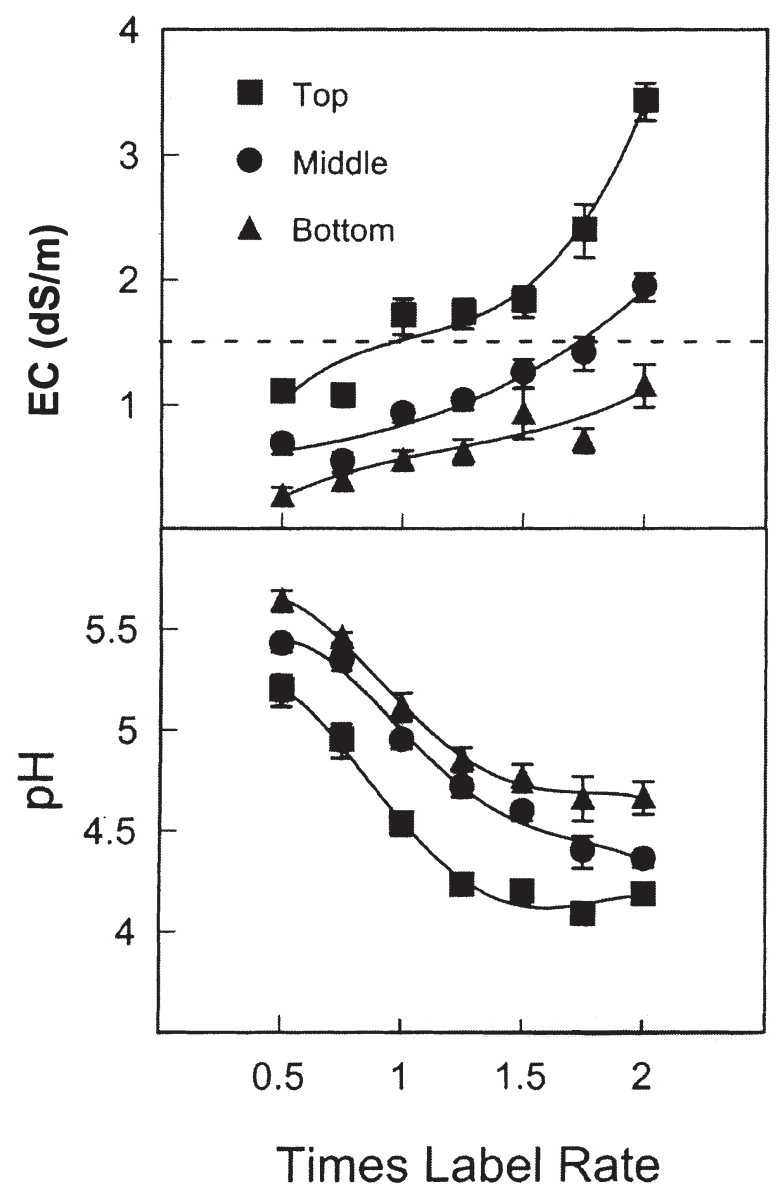

Fig. 3. EC and $\mathrm{pH}$ of the top, middle, and bottom layers of growing medium from New Guinea impatiens 'Illusion' grown at rates of $0.5,0.75,1.0,1.25,1.5$, 1.75 , and 2 times the manufacturer's recommended rate CRF in a recirculating subirrigation system (final harvest). Bars represent standard error of the mean. Dashed line represents the recommended maximum EC level of $1.5 \mathrm{dS} \cdot \mathrm{m}^{-1}$.

Table 4. Percent potassium from CRF recovered in plant tops, media + roots, prills, and leachate recovered over time for New Guinea impatiens 'Illusion' grown in a recirculating subirrigation and top-watered irrigation system (final harvest).

\begin{tabular}{|c|c|c|c|c|c|c|c|}
\hline \multirow[b]{3}{*}{ Day } & \multicolumn{7}{|c|}{$\%$ Potassium $^{2}$} \\
\hline & \multirow[b]{2}{*}{ Plant tops } & \multicolumn{3}{|c|}{ Media (+ roots) ${ }^{y}$} & \multirow[b]{2}{*}{ Prills } & \multirow{2}{*}{$\begin{array}{l}\text { Recirculating } \\
\text { solution }{ }^{x} \text { or } \\
\text { leachate }\end{array}$} & \multirow[b]{2}{*}{ Total } \\
\hline & & Top & Middle & Bottom & & & \\
\hline \multicolumn{8}{|c|}{ Recirculating subirrigation } \\
\hline 0 & --- & --- & -- & -- & 100 & $n d^{\mathrm{x}}$ & $100 \pm 4.93^{v}$ \\
\hline 14 & 2.8 & 5.99 & 3.17 & 2.23 & 77.1 & nd & $91 \pm 3.92$ \\
\hline 28 & 8.2 & 11.74 & 5.42 & 2.35 & 77.9 & nd & $106 \pm 4.06$ \\
\hline 42 & 14.9 & 7.55 & 1.98 & 4.52 & 68.4 & nd & $100 \pm 2.80$ \\
\hline 56 & 23.6 & 4.51 & 5.27 & 2.69 & 62.6 & nd & $99 \pm 6.78$ \\
\hline 70 & 35.0 & 5.86 & 6.02 & 2.84 & 51.3 & nd & $101 \pm 3.67$ \\
\hline 84 & 41.4 & 5.88 & 9.61 & 7.03 & 45.9 & nd & $110 \pm 9.40$ \\
\hline \multicolumn{8}{|c|}{ Top-watered } \\
\hline 0 & --- & --- & --- & --- & 100 & --- & $100 \pm 4.93^{v}$ \\
\hline 14 & 3.5 & 4.81 & 7.91 & 6.32 & 92.2 & $8.20^{\mathrm{w}}$ & $123 \pm 9.66$ \\
\hline 28 & 8.2 & 2.04 & 5.77 & 2.62 & 79.8 & 2.23 & $101 \pm 4.65$ \\
\hline 42 & 18.2 & 4.93 & 4.91 & 3.84 & 68.6 & 3.97 & $104 \pm 4.18$ \\
\hline 56 & 24.3 & 3.25 & 3.17 & 2.64 & 61.2 & 3.43 & $98 \pm 4.12$ \\
\hline 70 & 31.0 & 2.52 & 3.84 & 4.85 & 54.4 & 4.39 & $101 \pm 4.16$ \\
\hline 84 & 45.8 & 1.41 & 4.45 & 3.07 & 45.1 & 3.84 & $104 \pm 5.96$ \\
\hline \multicolumn{8}{|c|}{ Significance } \\
\hline Irrigation method (IM) & NS & & $* * *$ & & NS & & \\
\hline Day & $* * *$ & & $*$ & & $* * *$ & $* * *$ & \\
\hline IM $\times$ day & NS & & $* * *$ & & NS & & \\
\hline Layer & & & $* * *$ & & 10 & & \\
\hline $\mathrm{IM} \times$ layer & & & $* * *$ & & & & \\
\hline Day $\times$ layer & & & * & & & & \\
\hline $\mathrm{IM} \times$ day $\times$ layer & & & $* * *$ & & & & \\
\hline
\end{tabular}

${ }^{2}$ Data represent means of five replications.

${ }^{y}$ Media divided into top, middle, and bottom thirds, with respect to height of the container.

$\mathrm{x} \% \mathrm{~K}$ recovered in recirculating solution; $\mathrm{nd}=$ not detectable.

w\% K recovered in leachate at 0.4 leaching fraction.

${ }^{v}$ Average total $\% \mathrm{~K} \pm$ standard deviation of the mean; $100 \%$ equals $577 \pm 28.5 \mathrm{~g} \mathrm{~K}$ added per container.

Ns, ${ }^{*, * * *}$ Nonsignificant or significant at $P<0.05$ or 0.001 , respectively. 


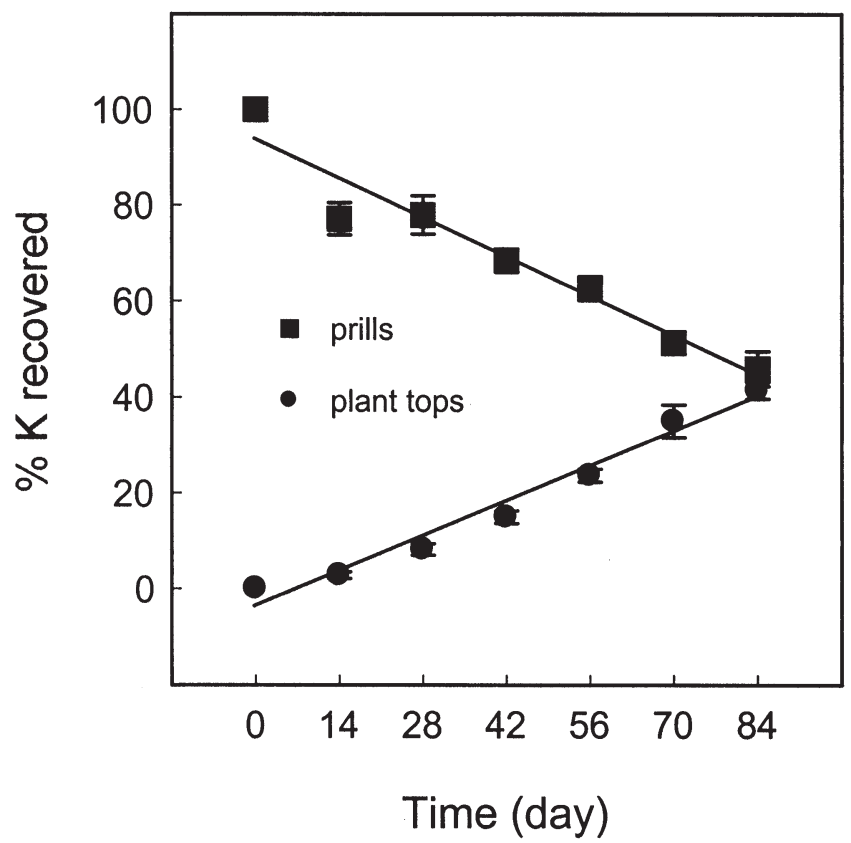

Fig. 4. Percent K remaining in prills and recovered from plant tops of New Guinea impatiens 'Illusion' grown with the label recommended rate $\mathrm{CRF}$ in a recirculating subirrigation system. Percent $\mathrm{K}$ remaining in prills can be expressed by $\mathrm{y}=0.880 \mathrm{x}-0.005$, with $R^{2}=0.745(P=0.0001)$; percent $\mathrm{K}$ recovered from plant tops can be expressed by y $=0.006 \mathrm{x}-0.073$, with $R^{2}=0.921(P=0.0001)$. Bars represent standard error of the mean.

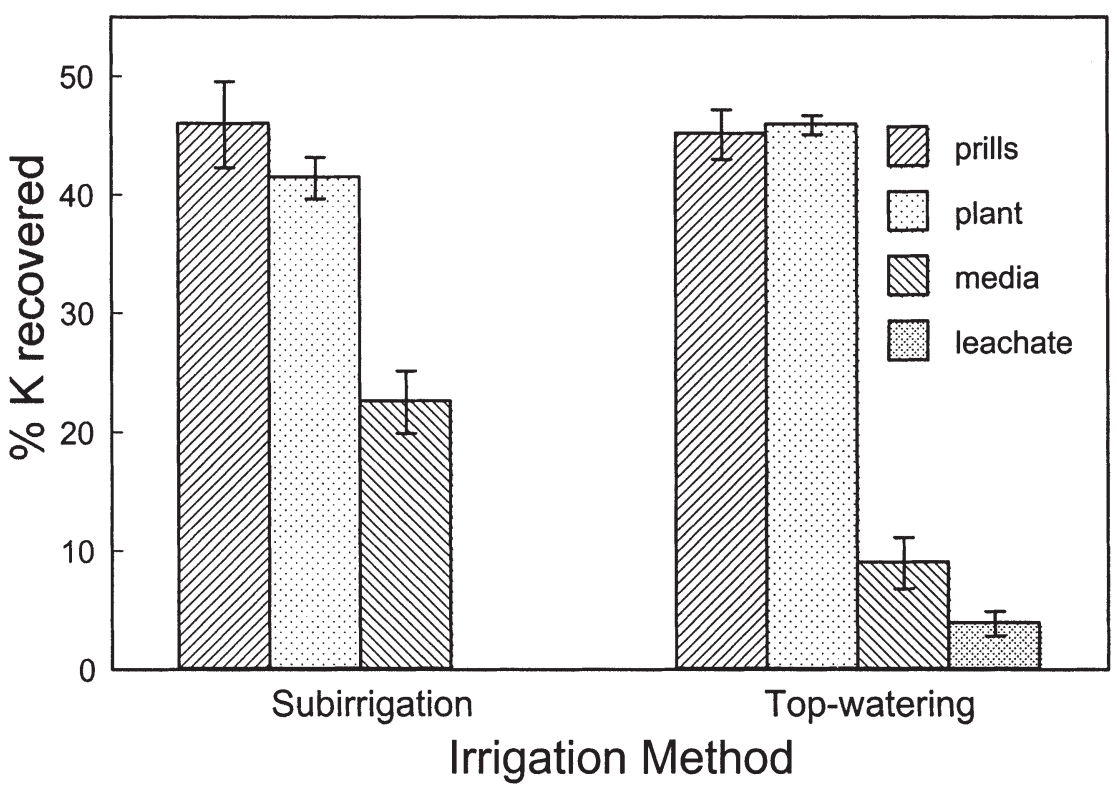

Fig. 5. Complete K balance for New Guinea impatiens 'Illusion' grown with the label recommended rate of CRF in recirculating subirrigated and top-watered systems (final harvest). Bars represent standard error of the mean.

there is virtually no downward leaching in subirrigation, even from the lower flooded portion of the container. However, one could consider accumulation of salts in the top layer (Fig. 4, Table 4) upward leaching out of the root zone.

For total $\mathrm{K}$ balance at final harvest, both $\mathrm{K}$ recovered in plant tops and $\mathrm{K}$ released from the prills were not significantly different between irrigation methods (Table 4, Fig. 5). About 45\% of the original $\mathrm{K}$ was still in the prills at final harvest. This is equivalent to slightly greater than half of the $\mathrm{K}$ being released after about three-fourths of the manufacturer's stated useful product life $\left(\approx 112\right.$ days at $\left.21^{\circ} \mathrm{C}\right)$.

Calculations of fertilizer use efficiency (proportion of $\mathrm{K}$ recovered in plant tops to $\mathrm{K}$ released from the $\mathrm{CRF}$ ) for this experiment were $77 \%$ and $83 \%$ for subirrigation and top-watering, respectively. However, this is an underestimate since $\mathrm{K}$ in roots was not measured. These results indicate that CRFs have a very high fertilizer use efficiency and are similar to those reported by Holcomb
(1980), who found the fertilizer use efficiency of Osmocote CRF to be $89 \%$ and that of a comparable water-soluble fertilizer to be only $46 \%$ (irrigation method not listed). Similarly, Morvant et al. (2001) found a combination of CRF and subirrigation yielded $90 \%$ fertilizer use efficiency.

In summary, with respect to placement, New Guinea impatiens grown with CRF incorporated were slightly larger than were those grown with CRF top-dressed, dibbled, or placed in the bottom of the pot (Table 1). For New Guinea impatiens grown in recirculating subirrigation, the optimum rate was determined to be the $1.3 \times$ rate (Table 3 , Fig. 2 ). These results are consistent with those found by other researchers who found recommended CRF rates were too low for many plant species (Kovacic and Holcomb, 1981; Lamont et al., 1990; Rauch, 1989), including New Guinea impatiens (Rauch and Murakami, 1994). This is contrary to soluble fertilizer added in subirrigation where lower than normally recommended rates for top-watering were found to be optimum (Kent and Reed, 1996; Reed, 1996). Both $\mathrm{K}$ recovered in plant tops and released from prills were approximately linear with respect to time, regardless of irrigation method. In recirculating subirrigation systems, a significant amount of $\mathrm{K}$ is accumulated in the upper layer of the growing media. The salts move up in the container profile with water and are left behind upon evaporation from the soil surface. This amounts to what could be called "upward leaching." In top-watered systems, very little $\mathrm{K}$ is lost as a result of leaching after the first two weeks. This is probably associated with root development and root absorption of the released $\mathrm{K}$, and the maintenance of low leaching fractions. This indicates that CRFs may successfully be used to reduce runoff of $\mathrm{K}$, even when plants are top-watered, if reasonably leached. An additional benefit of using CRFs is an extremely high fertilizer use efficiency.

\section{Literature Cited}

Argo, W.R. and J.A. Biernbaum. 1995. The effect of irrigation method, water-soluble fertilization, preplant nutrient charge, and surface evaporation on early vegetative and root growth of poinsettia. J. Amer. Soc. Hort. Sci. 120:163-169.

Biernbaum, J.A. 1992. Root-zone management of greenhouse container-grown crops to control water and fertilizer use. HortTechnology 2: 127-132.

Dahlquist, R.L. and J.W. Knoll. 1978. Inductively coupled plasma-atomic emission spectrometry: Analysis of biological materials and soils for major, trace, and ultra-trace elements. Appl. Spectroscopy 32:1-29.

Erwin, J., M. Ascerno, F. Pfleger, and R. Heins. 1992. New Guinea impatiens production. Minn. Commercial Flower Growers Assn. Bul. 41:1-15.

Hartley, D.E. 1995. Feeding and watering, p. 31-39. In: W. Banner and M. Klopmeyer (eds.). New Guinea impatiens: A Ball guide. Ball Publishing, Batavia, Ill.

Haver, D.L. and U.K. Schuch. 1996. Production and postproduction performance of two New Guinea impatiens cultivars grown with controlled-release fertilizer and no leaching. J. Amer. Soc. Hort. 121: 820-825. 
Havlin, J.L. and P.N. Soltanpour. 1980. A nitric acid plant tissue digest method for use with inductively coupled plasma spectrometry. Commun. Soil Sci. Plant. Anal. 11:969-980.

Holcomb, E.J. 1980. How to increase fertilizer efficiency through slow-release formulations. Amer. Nurseryman 62:9, 38, 40, 42.

Holcomb, E.J. 1981. Potassium release from selected slow-release fertilizers. Commun. Soil Sci. Plant Anal. 12:1303-1310.

Jarrell, W.M., S.J. Whaley, and B. Miraftabi. 1983. Slow-release fertilizer and water management with container-grown Ligustrum texanum. Scientia Hort. 19:177-190.

Johnson, C.R. and G.D. Warden. 1975. Influence of rate and placement of Osmocote on growth of container grown Celosia argentia. Proc. Southern Nurserymen's Assn. Res. Conf. 20:23.

Kent, M.W. and D.W. Reed. 1996. Nitrogen nutrition of New Guinea impatiens 'Barbados' and Spathiphyllum 'Petite' in a subirrigation system. J. Amer. Soc. Hort. Sci. 121:816-819.

Kovacic, M.T. and E.J. Holcomb. 1981. Effects of controlled-release fertilizers and application methods on growth and leaf elemental concentration of Kalanchoe blossfeldiana 'Pixie'. J. Amer. Soc. Hort. Sci. 106:549-552.

Lamont, G.P., R.J. Worrall, and M.A. O'Connell. 1987. The effects of temperature and time on the solubility of resin-coated controlled-release fertilizers under laboratory and field conditions. Scientia Hort. 32:265-273.

Lamont, G.P., G.C. Cresswell, and G.J. Griffith. 1990. Nutritional studies of Christmas Bell. HortScience 25:1401-1402.

Lang, H.J. 1996. Growing media testing and interpretation, p. 123-140. In: D.W. Reed (ed.). Water, media and nutrition for greenhouse crops. Ball Publishing, Batavia, Ill.

Molitor, H.D. 1990. The European perspective with emphasis on subirrigation and recirculation of water and nutrients. Acta Hort. 272:165-173.

Morvant, J.K., J.M. Dole, and J.C. Cole. 2001. Fertilizer source and irrigation system effect on geranium growth and nitrogen retention. J. Amer. Soc. Hort. Sci. 36:1022-1026.

Oertli, J.J. and O.R. Lunt. 1962. Controlled release of fertilizer minerals by incapsulating mem- branes: II. Efficiency of recovery, influence of soil moisture, mode of application, and other considerations related to use. Soil Sci. Soc. Amer. Proc. 28:584-587.

Rauch, F.D. 1989. Osmocote application trials with areca palm seedlings. Univ. of Hawaii Res. Ext. Ser. 103, p. 11-12.

Rauch, F.D. and P.K. Murakami. 1994. Comparison between two controlled-release fertilizers on selected foliage plants in an artificial potting mix. Fert. Res. 39:89-95.

Reed,D.W. 1996. Closed production systems for containerized crops: Recirculating subirrigation and zero-leach systems, p. 221-245. In: D.W. Reed (ed.). Water, media and nutrition for greenhouse crops. Ball Publications, Batavia, Ill.

Tran, T.S. and R.R. Simard. 1993. Mehlich III-extractable elements, p. 43-49. In: M.R. Carter (ed.). Soil sampling and methods of analysis. Lewis Publishers, Boca Raton, Fla.

Warncke, D.D. and D.M. Krauskopf. 1983. Greenhouse growth media: Testing and nutrition guidelines. Mich. State Univ. Coop. Ext. Bul. E-176 